Fra De Boghistoriske Samlinger

\section{Columbus i Det gamle Testamente - Agostino Giustinianis polyglotte Psalterium fra 1516}

\section{Afseniorforsker Karen Skovgaard- Petersen}

I 1516 udkom der i Genova en bog der i mange henseender er bemærkelsesværdig. I Det Kongelige Bibliotek findes hele to eksemplarer, det ene i det gamle Universitetsbiblioteks samlinger, det andet $\mathrm{i}$ Det Kongelige Biblioteks boghistoriske samlinger. (Billederne i denne artikel er af sidstnævnte eksemplar).

Bogen er et psalterium, dvs. en udgave af de gammeltestamentlige Davids Salmer - og det var der i sig selv intet usædvanligt ved. Salmerne var en del af Bibelen der ofte både i middelalderen og senere, optrådte i selvstændige bøger. De udgjorde en vigtig del af den kirkelige liturgi, og med deres rige billedsprog dannede de udgangspunkt for megen middelalderlig kirkelig digtning. Deres suggestive - ofte dunkle - poesi gjorde Salmerne til genstand for omfattende teologisk exegese, og det var et gennemgående træk i den middelalderlige fortolkning at de ansås for at indeholde profetier, især om Kristus, altså inden for rammerne af Det nye Testamente, men også om senere begivenheder, såsom korstogene, der dermed til- deltes en plads i den kristne verdenshistorie.

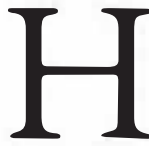
vad der gør dette psalterium fra 1516 opsigtsvækkende, er for det første sprogene. Det er en såkaldt polyglot bibeludgave, dvs. en flersproget udgave hvor de forskellige versioner er opstillet i kolonner - og den er en af de allerførste trykte af sin art. De mange sprog fremgår allerede af titlen på titelbladet: Psalterium, Hebreum, Grecum. Arabicum, o Chaldeum: cum Tribus Latinis

Interpretationibus \& Glossis. Udgiveren Agostino Giustiniani refererede selv til værket som „det otte-foldige Psalterium“. Hver salme er trykt i hele syv forskellige versioner, parallelt opstillet i spalter. Fra venstre til højre drejer det sig om følgende sprog: hebraisk, latinsk oversættelse heraf, latina communis (dvs. Hieronymus' latinske Vulgatatekst efter den græske septuagintaoversættelse $^{1}$ ), græsk (septuaginta-oversættelsen), arabisk, aramæisk (paraphrasis chaldaica, dvs. den såkaldte Targum, her trykt med hebraiske typer) og en latinsk oversættelse heraf. I en ottende spalte yderst til højre står så udgiverens kommentarer.

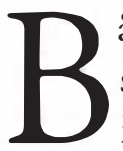
åde filologisk og typografisk er der således tale om en tour de force, hvor ikke alene flere sprog er repræsenteret, men også flere alfabeter - det latinske, græske, hebraiske og arabiske. Mens både græske og hebraiske skrifttyper var blevet taget $\mathrm{i}$ anvendelse i bogtrykkets første tid i anden halvdel af 1400-tallet, var brugen af arabiske skrifttyper en nyhed, og faktisk regnes bogen for at være det næstældste arabiske tryk overhovedet. Det samlede resultat er smukt. I kolofonen bagest, hvor trykkeren Petrus Paulus Porrus præsenteres, gøres det også klart at han har trykt bogen med uovertruffen dygtighed (miro ingenio). 


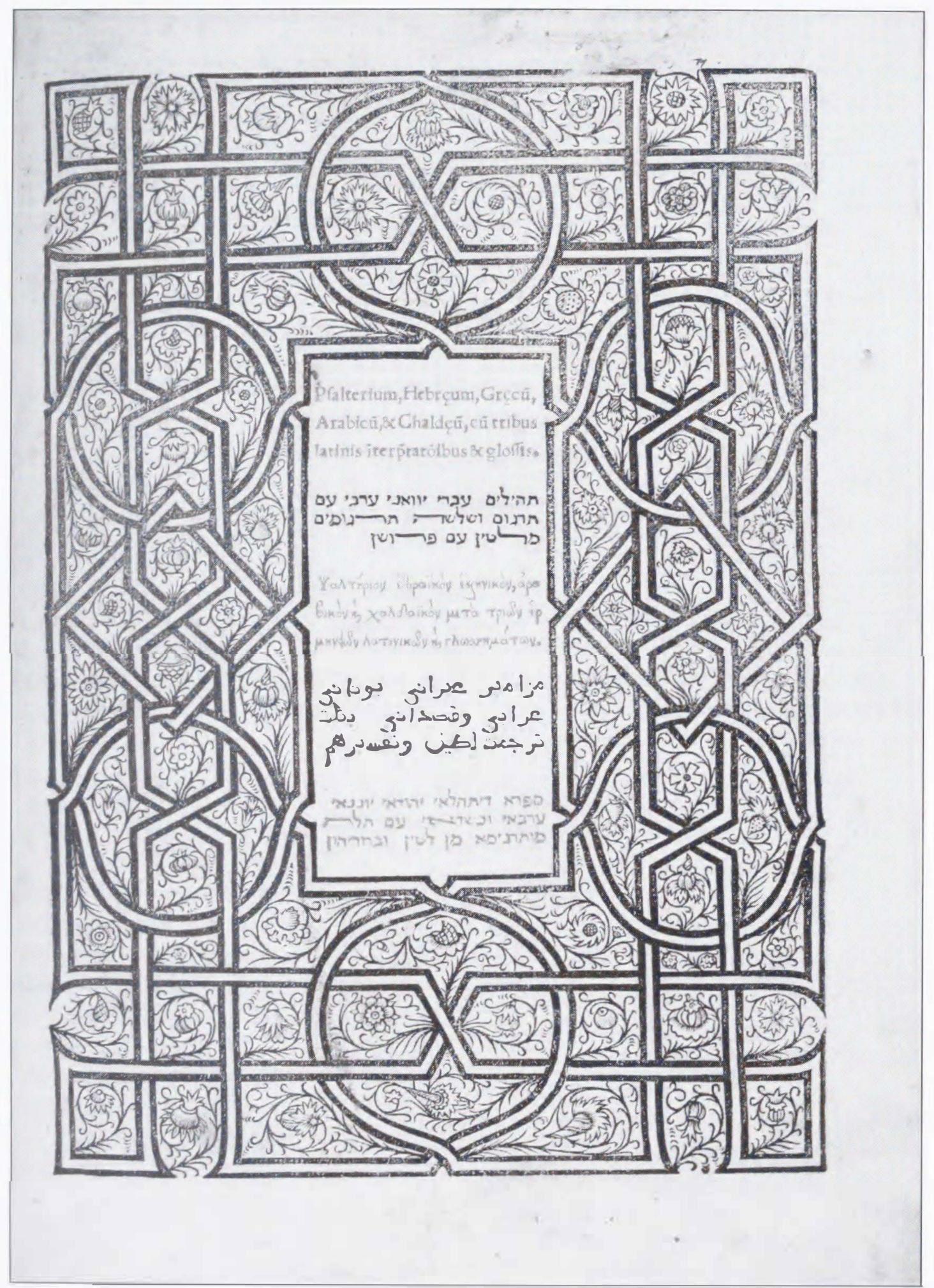

Titelbladet til I'saltcrium Hebreum, Grecum etc. Her er alle sprogene representeret. Tiksten er omgivet af en ornamental ramme med arabesker og blomstermotiver, en orientalsk inspireret stil, som ogsai ses pri mange bogbind fra Italien i det tidlige 16. airh. (Foto: Det Kongelige Bibliotek). 


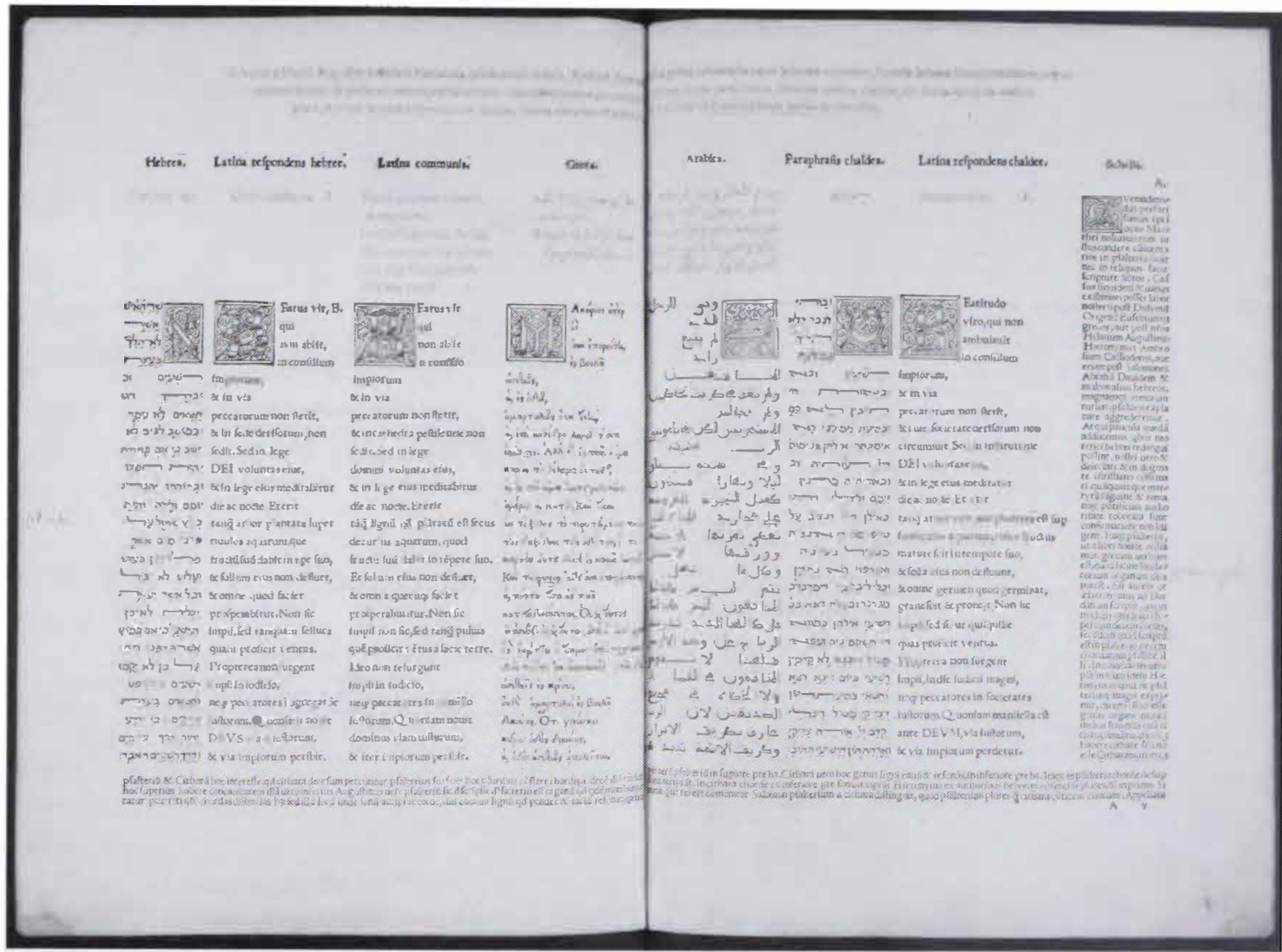

Her begynder Salmeteksten. ()verskriften gor rede for indholdet af de enkelte spalter. (Foto: Det Kongelige Bibliotek).

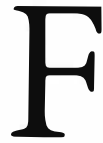
or det andet indtager Giustinianis Psalterium en betydningsfuld lærdomshistorisk plads i orientalistikkens historie. I sine kommentarer i 8. spalte citerer Giustiniani et væld af passager af centrale tekster af den jødiske kabbalistik, tilføjet hans egne oversættelser til latin tekster som dermed blev præsenteret for den europæiske lærde verden. ${ }^{2} \mathrm{Og}$ bogen kom også til at spille en rolle for kendskabet til arabisk. Med sine parallelt opstillede versioner gav den gode muligheder for den der ønskede at tilegne sig et af de eksotiske sprog, og flere af 1500-tallets store arabiske filologer drog nytte af Psalteriet i den henseende. ${ }^{3}$

For det tredje - og ganske overraskende i betragtning af indholdet iøvrigt - påkalder bogen sig opmærksomhed ved at bringe den første trykte beretning om Christopher Columbus' liv, ti år efter hans død i 1506. Denne biografi findes i en af udgiverens noter, nærmere bestemt $\mathrm{i}$ kommentaren til Salme 19 (Salme 18 i den latinske Vulgatas tælling). Hvad der har fået Agostino Giustiniani til at indlemme denne lille biografi - som han selv havde forfattet i sin salmekommentar, skal vi vende tilbage til. Først en nærmere præsentation af bogen og dens udgiver.

\section{Agostino Giustiniani}

A gostino Giustiniani levede fra 1470 til $1536 .{ }^{4} \mathrm{Han}$ var af en velhavende Igenovesisk familie. Som ung, i 1488, lod han sig optage i Dominikanerkonventet 
S. Apollinare i Pavia. Her må han have givet sig i kast med at studere de eksotiske sprog som han senere inddrog i sit Psalterium, og åbenbart havde han allerede erhvervet sig betydelige kundskaber i det første årti af 1500-tallet. Efter i et par år at have undervist i Bologna, opnåede han i 1514 tilladelse fra sine overordnede til at hellige sig en samlet udgave af Bibelen på hebraisk, chaldæisk, latin og arabisk, og som et første resultat kunne han altså i 1516 udsende sit otte-foldige Psalterium. I sit dedikationsbrev til Pave Leo X antyder han at han næsten er ved vejs ende med den samlede bibeltekst $\mathrm{i}$ denne polyglotte form. Han hævdede selv senere (i den selvbiografiske passage i Genovahistorien, jf. note 4) at have færdiggjort Det nye Testamente på græsk, latin, hebraisk og arabisk, og det fremgår også flere steder $\mathrm{i}$ kommentarerne at han allerede er langt med resten af bibelteksten. Ikke desto mindre fik han aldrig udgivet mere end Psalteriet af dette værk.

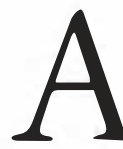
llerede før udgivelsen af Psalteriet var han blevet udnæunt til biskop af Nebbio, dvs. biskop på Korsika som hørte under Genova, og som sådan præsenterer han sig også i Psalteriet. Hans kundskaber i orientalske sprog var anerkendte, og $\mathrm{i}$ 1518 blev han af den humanistisk interesserede Kong Frans I kaldt til Paris, hvor han virkede som lærer i orientalske sprog. Her udsendte han flere værker, bl.a. en hebraisk grammatik. Omkring 1522 vendte han tilbage til sit virke som biskop af Nebbio og tilbragte resten af sit liv dér og i Genova. I denne periode skrev han, på italiensk, en Genova-historie som også rummer en lille selvbiografi. Den blev trykt året efter hans død (Castigatissimi annali ... della eccelsa \& illustrissima Republica di Genoa (Genova 1537)).
Samtidige polyglotte udgivelser

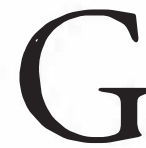
iustinianis polyglotte psalter var ikke en enlig svale. Da det udkom i 1516, havde en gruppe lærde i den spanske by Alcalá de Henares gennem mange år - siden 1502 - under ledelse af kardinal Franciscus Ximenes arbejdet på en stor polyglot Bibeludgave. Dette værk blev trykt i årene 1514-17 i seks bind, men blev først publiceret i 1521-22, da det trak ud med den pavelige autorisation. Den benævnes som oftest Complutenserbibelen efter det latinske navn for Alcalá, Complutum. Erasmus af Rotterdam kunne - også i 1516 - udsende Det nye Testamente på græsk med latinsk oversættelse trykt i to spalter på hver side. Samme år udkom i Basel - som del af den senantikke kirkefader Hieronymus' samlede værker - et Psalterium trykt i fire spalter, nemlig græsk og hebraisk samt Hieronymus' oversættelser til latin fra disse to sprog (jf. note 1 ). $\mathrm{Og}$ allerede i årene omkring 1500 havde den banebrydende venetianske trykker Aldus Manutius haft planer om at udgive en flersproget bibel. Også i de følgende århundreder blev der udgivet mange polyglotte bibler og dele af bibelen.

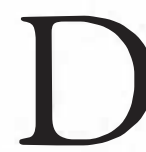
e polyglotte bibeludgivelser var udtryk for en historisk og filologisk interesse i studier af bibelteksten.

En afgørende forudsætning var det, at man i denne periode fik større kendskab til håndskrifter der rummede græske, hebraiske, arabiske og aramæiske bibeltekster. Disse filologisk prægede bibelstudier er nært beslægtede med periodens - Renæssancens - interesse i at opspore og studere håndskrifter med tekster fra den græsk-romerske oldtid. Den traditionelle latinske Vulgatatekst kunne nu sammenlignes med andre - og ældre - teksttraditioner. 


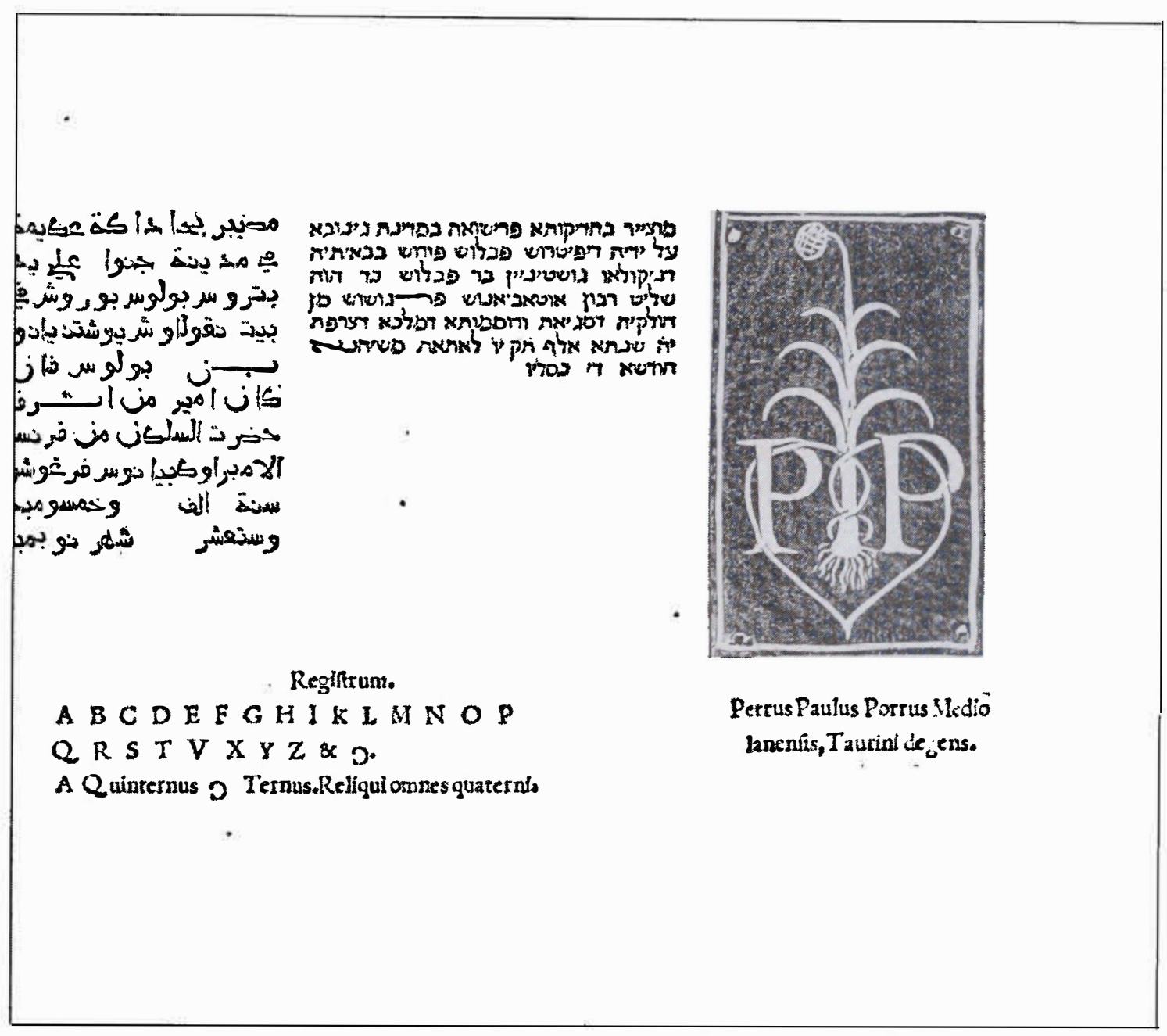

Trykkeren Petrus Paulus Porrus' trykkermarke, anbragt bagest i bogen. En porre - på latin porrum - i et hjerte samt initialerne P P. Sädanne bogtrykkermarker var udbredte i 1500-tallet. Med billede og bogstaver angaves trykkerens identitet. Petrus Porrus, der stammede fra Milano men havde släet sig ned i Torino, var blevet kaldt til Genova vist netop til denne opgave. (Foto: Det Kongelige Bibliotek).

Giustiniani understreger således i sin dedikation til Pave Leo X at det måtte være helt centralt for en gejstlig at beskæftige sig med fortolkninger og oversættelser af den hellige skrift, og han tilføjer at han selv er $\mathrm{i}$ besiddelse af gamle håndskrifter der viser at sådanne udlægninger blev foretaget både på latin, græsk, hebraisk, aramæisk og arabisk. ${ }^{5}$ Det er altså ønsket om en bedre forståelse af bibelteksten der er drivkraften bag de polyglotte udgivelser. Dertil kommer så at de har kunnet tjene som redskab til at lære de gamle, eksotiske sprog - for den der i forvejen beherskede latin. Netop Giustinianis Psalterium fik som nævnt betydning for studiet af arabisk i Europa.

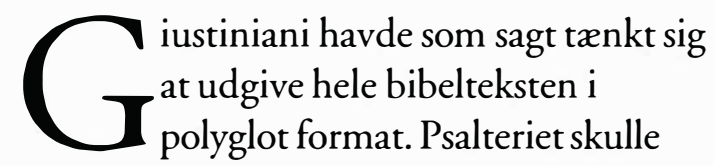
være en første prøve på det store værk. Han var altså ikke mindre ambitiøs end kardinal 
Ximenes og hans folk, og det er ganske sandsynligt at Giustiniani så sit projekt som et modstykke, en konkurrent, til det store spanske arbejde."

$\mathrm{P}$ salteriet opnåede dog kun begrænset succes. For egen regning havde Giustiniani ladet det trykke i et ganske anseligt antal eksemplarer, 2000, hvortil kom 50 særlig luksuriøse eksemplarer trykt på pergament, beregnet som fyrstelige gaveeksemplarer. Afsætningen gik imidlertid trægt, og Giustiniani fortæller selv med tydelig bitterhed i sin selvbiografi i Genovahistorien at han kun fik solgt 500 eksemplarer. 'Han havde forestillet sig, skriver han, at højtstående personer - og vel ikke mindst dem til hvem han forærede de særligt fine pergamenteksemplarer - ville være med til at finansiere det store polyglotte bibelprojekt. Under alle omstændigheder afstod han fra at fortsætte. Men trods den ringe kommercielle succes nød bogen som antydet stort ry blandt orientalske lærde i de næste århundreder - ikke bare som middel til at erhverve sig kundskaber i arabisk, men også på grund af den kabbalistiske lærdom Giustiniani lagde for dagen i sine kommentarer. "Man roste hans Psalterium og købte det ikke", som Pierre Bayle lakonisk skrevi en revideret udgave af sit leksikon 200 år senere (3. udg. 1720).

\section{Columbus-biografien}

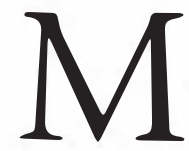
en bogen mødte også kritik. Erasmus af Rotterdam udtalte sig nedladende om den, hvad han dog senere, da han havde stiftet personligt bekendtskab med Giustiniani, fortrød. En anden lidt senere kritiker var Fernando Colón, søn af Christopher Columbus. Han tog anstød af den biografi som Giustiniani havde givet af Columbus i sin kommentar til
Salme 19. Særlig var det vistnok Giustinianis indledende oplysning om at Columbus var født i Genova i små kår Colón ikke brød sig om - en påstand Giustiniani senere gentog $\mathrm{i}$ sin Genova-historie.

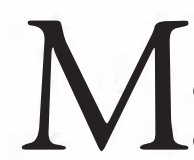
en trods sønnens utilfredshed er det nu et udpræget helteportræt der tegnes i den lille biografisom altså er den første skildring af Columbus' liv på tryk. Columbus hyldes eftertrykkeligt som den nye verdens opdager.

Giustiniani fortæller først hvordan Columbus tidligt i sin ungdom fulgte sin bror til Portugal og dér lagde sig efter at udarbejde kort over forskellige havne. Han kom også i kontakt med folk der havde rejst til fjerne lande, og deres beretninger sammenholdt med skriftlige geografiske fremstillinger overbeviste ham efterhånden om muligheden af at finde "enten en $\emptyset$ eller områder der hang sammen med det yderste Indien" (aut insulam aliquam, aut ultimas indorum continentes terras). Han fik kontakt med den spanske konge, som godt kunne se hvilken ære der ville tilfalde ham ved at stå bag denne ekspedition, særlig i konkurrencen med den portugisiske konge. Herefter hører vi om Columbus' første rejse - hvordan han overfor sine opgivende sømænd insisterede på at de ville finde nyt land, hvordan de første mennesker de fik kontakt med viste sig at være kannibaler, og hvordan de siden fik kontakt med andre mennesker hvis vilde levevis Giustiniani så dvæler ved. Efter sin hjemkomst, fortæller Giustiniani, blev Columbus hyldet som opdageren af en ny verden. Og kort efter begyndte man at udruste langt større ekspeditioner. På dette sted anslår Giustiniani en moraliserende tone og beklager at Spanien sender sin gift til den uskyldige verden, hvor overdådigheden luxus - nu holder sit indtog. Så rettes 
opmærksomheden igen mod Columbus og hans anden rejse, hans videre udforskning af området og udregning af dets beliggenhed $\mathrm{mm}$. Giustiniani runder af med at fortælle om hvordan den spanske konge lod Columbus' søn efterfølge ham som øverstkommanderende efter hans død - og hvordan Columbus selv betænkte sin fødeby ved at sørge for at en del af hans store rigdomme kom den til gode. „Dette var den vidtberømte mands endeligt. Havde han været født på den tid da de græske heroer levede, var han givetvis blevet optaget i gudernes tal", slutter Giustinani med eftertryk.

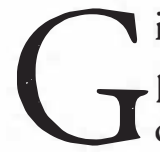

iustiniani havde naturligvis et patriotisk motiv til at offentliggøre denne skildring. Han var som sagt selv fra Genova. Columbus' genovesiske oprindelse fremhæves både først og sidst i den lille biografi, der iøvrigt er både summarisk og sine steder tydelig fejlagtig. Der er jo også en lille ironi i Giustinianis lovprisning af Columbus som den nye verdens opdager, i betragtning af at han vistnok aldrig selv opgav troen på at det var en del af Indien han var kommet til.

Men hvorfor valgte Giustiniani at anbringe sin hyldest til Columbus i denne sammenhæng? Columbusbiografien fungerer som udgiverens kommentar til en passage fra Salme 19. Denne salme begynder med at slå fast at Himlen, hvælvingen, dag og nat alle uden ophør og overalt forkynder Guds herlighed: „deres røst når ud over hele jorden, deres ord til verdens ende", som det hedder i den nye danske bibeloversættelse eller i den latinske Vulgatatekst hos Giustiniani: In omnem terram exiuitsonus eorum, \& in fines orbis terre verba eorum. Det er netop disse ord om at Guds ord når ud til verdens ende der er udgangspunktet for
Columbus-biografien. Giustiniani indleder den med ord der kommer direkte i forlængelse af salmepassagen: ,... nemlig omsider $\mathrm{i}$ vor tid, da næsten en ny verden er blevet fundet ved genoveseren Christopher Columbus' mirakuløse indsats og er blevet føjet til den kristne verden ". ${ }^{\circ}$ Salmens ord om Guds ords udbredelse forstås altså som noget fremtidigt, en profeti der nu med Columbus er gået i opfyldelse. Og det var netop sådan Columbus selv så sin opdagelse, fortsætter Giustiniani: "Eftersom Columbus ofte hævdede at han var udvalgt af Gud for at denne profeti skulle gå i opfyldelse, mener jeg det vil være på sin plads at bringe en beretning om hans liv på dette sted"." Columbus har med andre ord opfyldt den profeti om Guds ords udbredelse som salmen indeholder - og denne skelsættende begivenhed, understreger han, har fundet sted "i vor tid". Ser man efter i Giustinianis øvrige salmekommentarer, finder man at det slet ikke er den eneste gang han anlægger en profetisk synsvinkel. Han følger med andre ord den veletablerede opfattelse, at Salmerne indeholder profetier. Således fortolker han en omtale af Egypten og Ethiopien i Salme 68 som en forudsigelse om disse områders omvendelse til kristendommen foranlediget af evangelisterne Marcus og Matthæus, ligesom ordene Guds fjender i Salme 74 efter hans mening er en reference til Muhammed, og tilsvarende ser han i Salme 89 en henvisning til apostlene i Det nye Testamente.

olumbus-noten er simpelthen en
udlægning af Salmens profeti om
Guds ords udbredelse, hvor
Giustiniani viser at Columbus' opdagelse af
den nye verden har sin plads i den kristne
frelseshistorie. Dermed er Giustinianis
Columbusbiografi endnu et eksempel på det


fænomen som den amerikanske læerdomshistoriker Anthony (irafton har sammenfattet i bogtitlen Neu' Worlds, Ancient Texts
(1992), at opdagelsen af den nye verden blev inclpasset i den gamle verdens fortolkningsrammer.

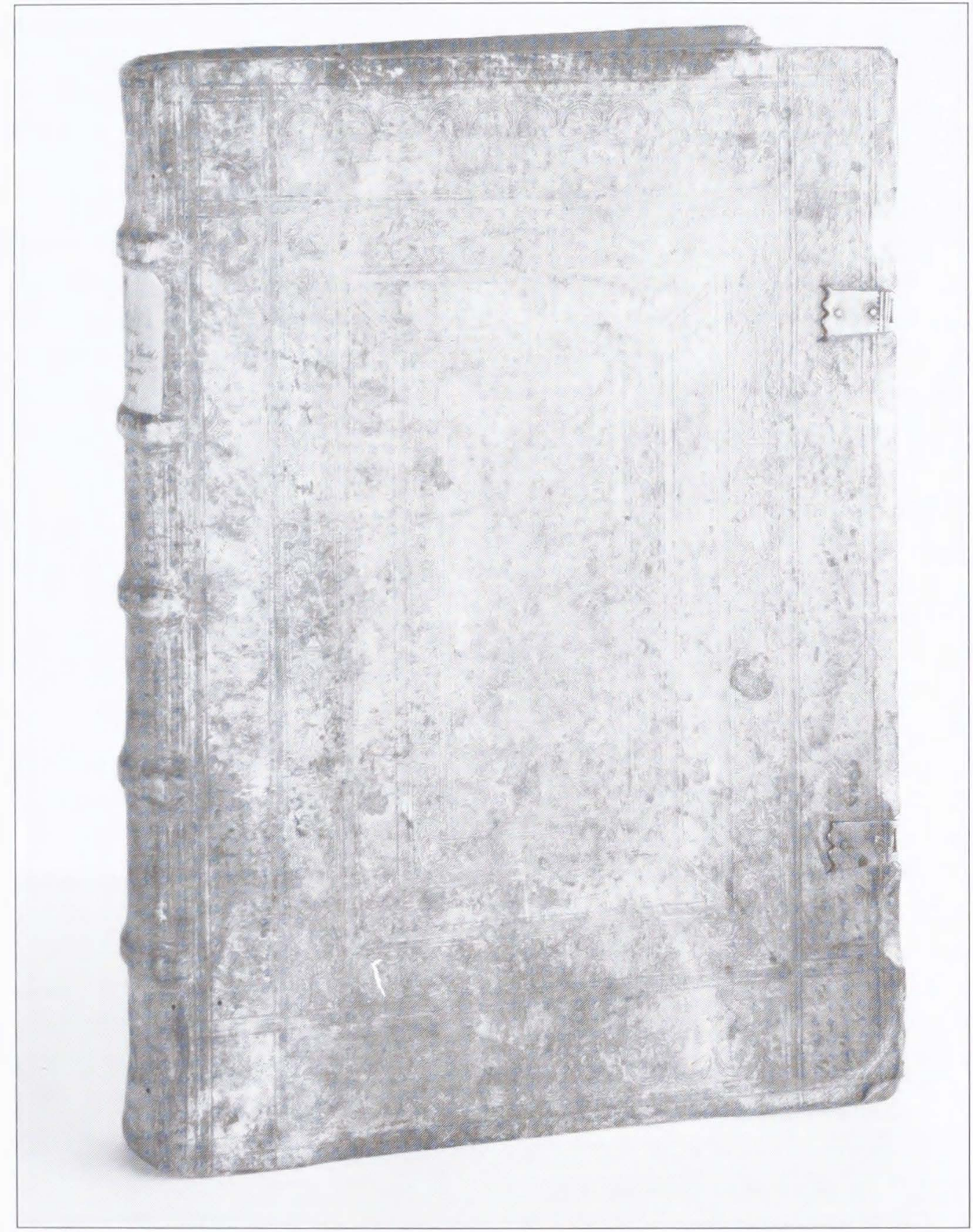

Det Kongelige Biblioteks eksemplar er indbundet i lyst skindbind fira 150()-tallet. Bogen giver ikke besked om sine tidligere ejere. Men mange haindskreune noter og understregninger, formentlig fra 15()(1)-tallet, vidner om opmarksom lasning. Dertil kommer en haindskrenen not its pai indersiden af bindet om erhuervelse af bogen, vist nok ogsia fia 150()-tallet. Huornir bogen er kommet til Det Kongelige Bibliotek, vides ikke med sikkerhed, men muliguis har biade den og Universitetsbiblioteketseksemplar tilhort (iren" Otto Thott (1703-85), som testamenterede sin store mangde tidlige tryk til Det Kongelige Bibliotek. Blandt dem v'ar to eksemplarer af Giustinianis Psalterium. (Foto: Det Kgl. Bibliotek). 
Noter:

' Der er tale om Hieronymus' reviderede salmeoversættelse, det såkaldte Psalterium Gallicanum (fra beg. af 390erne).

Hieronymus havde også tidligere, i beg. af 380erne, foretaget en salmeoversættelse til latin efter den græske septuaginta,

Psalterium Romanum. Senere, omkring 400, udarbejdede han endnu en latinsk salmeoversættelse, denne gang fra hebraisk, og både den og Gallicanum-oversættelsen indgår i den moderne Vulgata.

2 F. Secret: Les kabbalistes chrétiens de la renaissance (Paris: Dunod 1964), s. 101.

' Se Hartmut Bobzins artikel „Agostino Giustiniani (1470-1536) und seine Bedeutung für die Geschichte der Arabistik" i samlingen XXIV. Deutscher Orientalistentag, ed. W. Diem \& A. Falaturi (Zeitschrift der deutschen Morgenländischen Gesellschaft, Suppl. VIII) Franz Steiner Verlag Stuttgart 1990, s. 131-39).

+ Oplysninger om Giustinianis liv er hentet fra en selvbiografi han indsatte i sin Genovahistorie Castigatissimi annali ... della eccelsa é illustrissima Republica di Genoa (Genova: Antonio Bellono 1537), fol. 23r-25r (under sit fødeår 1470). Hartmut Bobzin giver en kort gennemgang af hans liv og værker i artiklen nævnt i note 3 og i en artikel specielt om Giustinianis Columbusvita: „Die Columbusvita im Psalterium Octaplum des Agostino Giustiniani (Genua 1516)“, trykt i Columbus zuischen zwei Welten, ed. Titus Heydenreich, Vervuert Verlag, Frankfurt am Main 1992, I, s. 97-106.

' Nibil enim aque sacerdoti conuenit, quam sacrarum literarum expositio of interpretatio. Huiusmodi autem sacre interpretatementa scripture, olim tentata sunt é a grecis, ơ a latinis, quinetiam hebrai, chaldai, é arabes, eius conatus indicia posteris reliquere, quorum veneranda vetustatis é fidei apud me extant monimenta.

"Som foreslået af Hartmut Bobzin i artiklen om Columbusbiografien 1992 (jf. note 4).

Fra selvbiografien stammer også de øvrige oplysninger om oplaget.

${ }^{8}$ Saltem temporibus nostris quibus mirabili ausu christophori columbi genuensis, alter pene orbis repertus est christianorumque cetui aggregatus.

"At uero quoniam Columbus frequenter predicabat se a Deo electum ut per ipsum adimpleretur hec prophetia, non alienum existimaui uitam ipsius hoc loco inserere. 